University of Warwick institutional repository

This paper is made available online in accordance with

publisher policies. Please scroll down to view the document

itself. Please refer to the repository record for this item and our

policy information available from the repository home page for

further information.

To see the final version of this paper please visit the publisher's website. Access to the published version may require a subscription.

Author(s): Adair D. Richards, Alison Rodger

Article Title: Synthetic Metallomolecules as Agents for the Control of DNA Structure

Year of publication: 2007

Link to published version:

http://dx.doi.org/10.1002/chin.200725222

Publisher statement: Published in Richards. A. D. et al. (2007).

Synthetic Metallomolecules as Agents for the Control of DNA

Structure. ChemInform, pp. 471-483 


\section{Synthetic metallomolecules as agents for the control of DNA structure}

\section{AUTHORS DRAFT}

\section{Adair D. Richards ${ }^{a}$ and Alison Rodger* ${ }^{b}$}

DNA is often referred to as the molecule of life, since it contains the instructions for making the required proteins. However, it is 5 not simply a (genetic) code to be read; its structure has an important role in determining when and how much of a particular protein is made at any point in time. Furthermore, there are a range of special DNA structures, e.g. Holliday junctions, which play essential roles for the existence of life as we know it or as it will become. In this tutorial review the normal B-DNA structure is summarised and metallomolecule binding modes discussed then used as a basis for examining DNA structures which can be induced by molecules containing metallic cations. The effects of aquated metal ions, cobalt ammine and ruthenium octahedral 10 metal complexes, metallo helicates and platinum complexes such as cis-platin are discussed alongside techniques such as NMR, X-ray crystallography, gel electrophoresis, circular dichroism, linear dichroism and molecular dynamics.

\section{Introduction to DNA}

In 1868 Miescher $^{1}$ first isolated cell nuclei from pus cells 15 and observed the presence of a phosphorus-containing compound. The resulting nucleic acids were found on hydrolysis to yield the purine bases: adenine and guanine and the pyrimidine bases: thymine and cytosine (Fig. 1.1). In 1950, Chargaff observed that the molar ratios of total 20 purines to total pyrimidines was close to 1 , and that in deoxyribonucleic acid (DNA), the amounts of adenine and thymine were equivalent and of guanine and cytosine were also equivalent. ${ }^{2}$ Three years later, Watson and Crick proposed a DNA structure made of two helical chains, 25 consisting of phosphate diester groups joining deoxyribofuranose residues, held together by purine and pyrimidine bases. ${ }^{3}$ The combination of the base and sugar is called a nucleoside, which upon addition of a phosphate group generates a nucleotide.

${ }_{30}$ Watson and Crick also suggested that the two helical chains were joined together in pairs, a single base from one being hydrogen bonded to a single base from the other chain and, using Chargaff's rule, that one base had to be a purine (A or $\mathrm{G}$ ) and the other a pyrimidine ( $\mathrm{T}$ or $\mathrm{C}$ ). ${ }^{3}$ Furthermore, 35 the normal pairings of bases are adenine with thymine and guanine with cytosine. The pairs of bases, being planar, can be stacked one above the other. The molecule is therefore represented as a spiral staircase with the base pairs forming the steps. DNA exists in biological systems mainly in so40 called B-form which is a right-handed helical structure (Fig. $1.2)^{4}$ where the base pairs are perpendicular to the helix axis. Under idealised conditions, the diameter of the BDNA helix is $2 \mathrm{~nm}$, its pitch (the distance a helix resis along its axis per turn) is $3.4 \mathrm{~nm}$ and since there are 10 base pairs 45 in each turn of the helix, there is a distance of $0.34 \mathrm{~nm}$ between each base pair. The pairing of the non-symmetric bases and their stacking, at approximately a $36^{\circ}$ torsion angle (the angle between base pairs observed in the plane perpendicular to the helix axis), gives rise in B-DNA to a

\footnotetext{
${ }^{a}$ Molecular Organisation and Assembly in Cells Doctoral Training Centre, University of Warwick, Coventry CV4 7AL, UK.

${ }^{b}$ Department of Chemistry, University of Warwick, Coventry CV4 7AL, UK. E-mail: A.Rodger@warwick.ac.uk; Tel: 44 (0)2476 574696; Fax: 44 (0)2476 575795
}

50 small (minor) groove and a large (major) groove ${ }^{5}$ (Fig. 1.3). The realisation that the planar bases can associate in particular ways by means of hydrogen bonding was a major step in the understanding of the structure and function of DNA. ${ }^{6}$

55 It does not take much reading to recognise that DNA is a key molecule for the operation of almost any biological system, since it contains the instructions for making the correct proteins. However, it is not simply a genetic code to be read. One of the big challenges of today is to work out

60 how transcription of certain pieces of DNA occurs at the correct times and to the correct extent to maintain a viable system. It is reasonable to conclude that DNA structures are important in this control. Thus, once one has established the 'norm' (usually B-DNA) for a system it becomes extremely 65 attractive to find out about the deviations from this standard. In the case of DNA there are different polymorphs such as A-DNA and Z-DNA, each of which has roles to play. We also know there is a wide range of DNA structures without which biology would not be as we know it. 70 Holliday junctions (mobile junctions between four strands of DNA), ${ }^{7}$ for example, look like a mess of spaghetti until one sees a colour-coded ribbon version at which point it becomes apparent that this is a very clever way of exchanging genetic material during cell meiosis.

75 Rather than grasping the whole topic of DNA structure and all its roles, in this review a brief overview of how some metallobiomolecules can be used to control DNA structure is given. Metal copmlexes are particularly attractive systems to study as they are usually cationic 80 which ensures their attraction to DNA. Furthermore, the fact that in most such complexes the metal holds ligating organic molecules firmly in place means that the shape and surface featueres e.g. Hydrogen bond donors or acceptors can be used to affect the DNA-metallo complex interaction.

${ }_{85}$ In the text that follows some well-known examples are summarised and illustrate the variety of effects metallomolecules can have on DNA.

\section{Modes of molecular binding to DNA}

Despite the view often formed of DNA as a naked train ${ }_{90}$ track stretching out to infinity (on a molecular scale) this is 
not realistic. In practice DNA is wrapped up tightly like a ball of anionic (negatively charged) knitting wool. At the very least it needs some cationic species there to enable it to hold together. Much of this role in cell nuclei is provided by 95 histone proteins, however, metal salts and other small molecules such as polyamines (see below) contribute significantly to this task. When one wishes to consider DNA structure control by specific molecules, it is important to consider where and how they bind to the DNA. Often the 100 process of molecular recognition involves conformational adjustments on the part of the interacting species, and the DNA helix may end up considerably distorted. DNA distorting induced by molecules containing metals are the subject of this review. Three fundamentally different modes 105 of DNA binding by metallomolecules can be identified: non-specific external association, (major and minor) groove binding and intercalation between DNA bases.

\subsection{External association}

In 1968, Eichhorn discussed the ability of metal ions to 110 interact with DNA and suggested two essential binding modes: external association with the negatively charged phosphate backbone and interactions with the electron donor groups of the bases. ${ }^{8}$ (It should be noted that when we say 'metal ion', particularly in the context of transition 115 metals, that the ion almost certainly has at least a solvation sphere and may also have explicitly coordinated (attached) solvent molecules making it a larger entity.) The factors influencing the backbone mode of binding are predominately electrostatic interactions and include the 120 charge of the molecule, the ligand hydrophobicity and the total size of the ions. Metals can also bind covalently to the phosphate groups. One of the main consequences of external association of cations to the DNA backbone is that separate DNA duplexes associate together to form 125 aggregates or condensed structures rather than repel each other.

\subsection{Major and minor groove binding}

In 1981, Gale et al. ${ }^{9}$ noted that most small molecules that bind to B-DNA grooves do so either in or via the minor 130 groove of the double helix, while DNA binding proteins or gene-targeted oligonucleotides interact with the major groove (Fig. 1.2 and 1.3). The reason for this is that many DNA binding molecules are small, fairly flat and cationic so the minor groove presents a better receptor for such 135 molecules in terms of its size, flexibility, electrostatic potential and water bonding properties. ${ }^{6}$ Goodsell and Dickerson later observed that minor-groove-binding drugs have a characteristic structure, usually containing two to five aromatic heterocycles linked by amide or vinyl groups ${ }_{140}$ with cationic groups at either ends. ${ }^{10}$ Thus metal complexes do not fir neatly into the minor groove, though in some cases part of such a molecule may slot into the minor groove. ${ }^{\text {e.g. }} 11$ The minor groove binder illustrated in (Fig. 2.2.1) is stabilised on the DNA by van der Waals 145 interactions with the walls and floor of the groove, as well as hydrogen bonds with the concave curvature of the inner surface of the molecule complementing the convex surface of the floor of the DNA minor groove. Such molecules have a preference for $\mathrm{A}-\mathrm{T}$ rich sequences for which the groove 150 has a deeper electrostatic potential and less steric hindrance. As a general rule, minor groove binding molecules have little effect on the structure of the DNA to which they bind, for example having little or no effect on DNA circular dichroism (though the spectrum may change if the ligand 155 has a transition in the DNA region of the spectrum) or on the DNA orientation in a Couette flow linear dichroism cell (though the ligands themselves are being oriented as a result of binding). ${ }^{12}$

\subsubsection{Platinum molecules}

160 Despite the accepted preference of groove binding molecules for the minor groove, there are classes of small molecules which are accommodated by the major groove. For example, platinum complexes such as cis-platin (brand name Platinol, (Fig. 2.2.1.1), discovered by Rosenberg et $165 \mathrm{al.}^{13}$ ) and its second and third generation derivatives are major groove binders. They have proved to be the most extensively used anti-tumour agents invented to date. In 1970, the biological target of cisplatin was identified as DNA and it was shown to bind covalently to purine bases, 170 in particular the major groove N7 of guanines. ${ }^{14}$ and references within

In the context of this article, a key feature of the favoured binding mode of cis-platin to DNA is that it binds to two neighbouring guanines on the same strand and induces 175 unstacking of the bases at the Pt-binding site. This causes the DNA to kink by $53^{\circ}$ (Fig. 2.2.1.2). ${ }^{15}$ The first indication that cis-platin causes such a distortion was the crystal structure for the major cis-platin-DNA adduct, cis$\left[\mathrm{Pt}\left(\mathrm{NH}_{3}\right)_{2}\{\mathrm{~d}(\mathrm{pGpG})\}\right]$, obtained in $1988^{16}$ which showed the 180 platinum metal centre co-ordinated in a square planar mode to two cis ammine ligands and two guanine N7 atoms, in a manner that caused unstacking of the guanines. ${ }^{16}$ The concomitant bending and local unwinding of the DNA double helix caused by platinum binding are important 185 structural motifs; in recognition and differential processing of damaged DNA by repair enzymes or alternatively the binding of proteins which protect the lesion from repair as in the case of cis-platin. ${ }^{17}$

Over the last few years, the field of platinum anti-cancer 190 drug discovery has widened to polynuclear platinum complexes with Farrell reporting di- and tri-nuclear platinum complexes (Fig. 2.2.1.3) showing some unique potential anticancer agent properties and activities against cis-platin-resistant tumours. ${ }^{18}$

195 2.2.2 Ruthenium complexes

Scientists are also looking at the possibility of using transition-metals other than platinum as potential chemotherapy agents. Using different metals would offer possibilities such as having additional co-ordination sites, 200 different oxidation states and ligand affinities, as well as providing the opportunity for electrochemical or photodynamic therapy (treatment with light-activated drugs in vivo). ${ }^{19}$

In particular, Alessio and co-workers have prepared a 205 ruthenium(III) compound, imidazolium transimidazoledimethylsulfoxide tetrachlororuthenate, 
ImH[trans-RuCl${ }_{4}$ (DMSO)Im], (Fig. 2.2.2.1) which is the first ruthenium-based compound to undergo clinical trials for its anti-metastasic properties. $^{20}$ It currently has 210 successfully passed phase I clinical trials and entered phase II administered in combination with a primary antiblastic compound in the summer of 2006 in the Netherlands. Although the location of the molecule on DNA is not yet known, it does form inter-strand cross-links and appears to 215 be a groove binder.

Ruthenium (II) complexes have been widely used for binding studies for many years because of their stability (chemically, electrochemically, geometrically and enantiomerically) and also because of the sensitivity of their 220 photophysical properties (luminescence enhancement and absorption hypochromism in the intense metal to ligand charge transfer bands) to binding interactions with DNA. An extensive debate can be found in the literature even over the binding of the simplest of the metal complexes with 225 unsaturated ligands: ruthenium tris(1,10-phenanthroline), $\left[\mathrm{Ru}(\text { phen })_{3}\right]^{2+}$ (Fig. 2.2.2.2). One thing was clear to all workers and that was that the two enantiomers of this complex interacted differently with DNA. In terms of structural effects, Hiort et al. ${ }^{21}$ showed that the two 230 enantiomers had different effects on the ability of DNA to be flow oriented. $\Lambda$ did not alter the DNA orientation parameter until high loading whereas $\Delta$ reduced the orientation parameter by $50 \%$ at a DNA base:metal complex ratio of $\sim 40: 1$. Coggan et al. ${ }^{11}$ later concluded that at low 235 loading, $\Delta$ bound with two of its chelates inserted into the minor groove which distorts the DNA resulting in it bending and thus less effective orientation. $\Lambda$ by way of contrast fits snugly into the major groove with one chelate partially inserted at the edge of the base pairs and does not bend or 240 stiffen the DNA significantly.

\subsubsection{Metal ions}

Metal ions can have quite dramatic effects on DNA structure in addition to inducing aggregation or DNA bending (see above). For example, poly[d(G-C) $]_{2}$ DNA has 245 been shown to change from $\mathrm{B}$ form and stabilise in $\mathrm{Z}$ form when the chloride salts of $\mathrm{Mg}^{2+}, \mathrm{Ca}^{2+}, \mathrm{Cd}^{2+}, \mathrm{Hg}^{2+}$ or $\mathrm{Zn}^{2+}$ are added, even in relatively low concentrations. ${ }^{22}$ Available $\mathrm{x}$-ray data suggests that these ions bind in the major groove of B-DNA and cause the major groove to disappear, the 250 minor groove to deepen and the helix to become lefthanded.

\subsubsection{Cobalt ammines}

Another class of DNA structure altering metal complexes which have been extensively studied are cobalt ammines. 255 The original motivation for this work stemmed from their apparent ability to mimic the behaviour of two DNA binding polycations: spermidine $\left[\mathrm{H}_{3} \mathrm{~N}\left(\mathrm{CH}_{2}\right)_{3} \mathrm{NH}_{2}\left(\mathrm{CH}_{2}\right)_{4} \mathrm{NH}_{3}\right]^{3+}$ and spermine $\left[\mathrm{H}_{3} \mathrm{~N}\left(\mathrm{CH}_{2}\right)_{3} \mathrm{NH}_{2}\left(\mathrm{CH}_{2}\right)_{4} \mathrm{NH}_{2}\left(\mathrm{CH}_{2}\right)_{3} \mathrm{NH}_{3}\right]^{4+}$ which are present 260 in all cells. ${ }^{23}$ The precise cellular functions of polyamines are unclear but they are known to charge neutralise over $40 \%$ of chromosomal DNA and they inhibit damage by reactive oxygen species, radiation, and alkylating agents. Further, polyamines stabilise DNA to heat and induce and 265 stabilise A, B, Z (usually observed with alternating G-C sequences) and collapsed DNA structures such as toroidal condensates. They also readily induce structurally illdefined DNA aggregates. Cobalt(III) ammine transition metal complexes, e.g. $\left[\mathrm{Co}\left(\mathrm{NH}_{3}\right)_{6}\right]^{3+},(+)-\left[\mathrm{Co}(\mathrm{en})_{3}\right]^{3+}$, and $270(-)-\left[\mathrm{Co}(\mathrm{en})_{3}\right]^{3+}$ (en $=$ ethylenediamine) mimic different aspects of the DNA interaction of the small polyamine molecules spermidine and spermine. ${ }^{\text {references in } 24}$ From molecular modelling of $\left[\mathrm{Co}\left(\mathrm{NH}_{3}\right)_{6}\right]^{3+},(+)-\left[\mathrm{Co}(\mathrm{en})_{3}\right]^{3+}$, and $(-)-\left[\mathrm{Co}(\mathrm{en})_{3}\right]^{3+}$ with DNA it was concluded that the cobalt 275 ammines do not bind in the minor groove of DNA, and their residence times in the major groove decreases in the order spermine $>\left[\mathrm{Co}\left(\mathrm{NH}_{3}\right)_{6}\right]^{3+}>(+)-\left[\mathrm{Co}(\text { en })_{3}\right]^{3+}>(-)-$ $\left[\mathrm{Co}(\mathrm{en})_{3}\right]^{3+} \cdot{ }^{24}$ These amines bend DNA (as seen in gels and linear dichroism $(L D)$ ) as a precursor to condensing it and a 280 key feature was concluded to be the presentation of a triangular NNN face to the DNA to optimise the bendcausing interaction. A similar geometric argument is required for the induction of the $\mathrm{B} \rightarrow \mathrm{Z}$ transition. Crystal structure data are consistent with the formation of five 285 hydrogen bonds between $\left[\mathrm{Co}\left(\mathrm{NH}_{3}\right)_{6}\right]^{3+}$ and the major groove convex surface of Z-DNA, specifically to guanine O6 and N7 and phosphate oxygens, thus stabilising ZDNA. ${ }^{25}$ In a more extensive study the overall effectiveness of the amines in conferring thermal stability on the ct-DNA 290 was found to proceed in the order:

$$
\begin{aligned}
& \text { spermine }>(+)-\left[\mathrm{Co}(\text { en })_{3}\right]^{3+} \sim(-)-\left[\mathrm{Co}(\text { en })_{3}\right]^{3+} \sim \\
& {\left[\mathrm{Co}\left(\mathrm{NH}_{3}\right)_{6}\right]^{3+} \sim \text { spermidine }>\left[\mathrm{Pt}\left(\mathrm{NH}_{3}\right)_{4}\right]^{2+}>} \\
& {\left[\mathrm{Co}\left(\mathrm{NH}_{3}\right)_{5} \mathrm{H}_{2} \mathrm{O}\right]^{3+} \sim\left[\mathrm{Co}\left(\mathrm{NH}_{3}\right)_{5} \mathrm{Cl}\right]^{2+} \sim\left[\mathrm{Co}\left(\mathrm{NH}_{3}\right)_{5} \mathrm{Br}\right]^{2+}>\text { cis- }} \\
& 295\left[\mathrm{Co}(\mathrm{en})_{2} \mathrm{NH}_{3} \mathrm{Cl}\right]^{2+}>\left[\mathrm{Co}\left(\mathrm{NH}_{3}\right)_{5}\left(\mathrm{NO}_{2}\right)\right]^{2+} \sim \text { trans- } \\
& {\left[\mathrm{Co}\left(\mathrm{NH}_{3}\right)_{4}\left(\mathrm{H}_{2} \mathrm{O}\right)_{2}\right]^{3+}}
\end{aligned}
$$

whereas the $\mathrm{B} \rightarrow \mathrm{Z}$ transition induction ordering is:

soo spermine $\approx\left[\mathrm{Co}\left(\mathrm{NH}_{3}\right)_{6}\right]^{3+}>(+)-\left[\mathrm{Co}(\mathrm{en})_{3}\right]^{3+} \approx$ $\left[\mathrm{Co}\left(\mathrm{NH}_{3}\right)_{5}\left(\mathrm{H}_{2} \mathrm{O}\right)\right]^{3+}>(-)-\left[\mathrm{Co}(\mathrm{en})_{3}\right]^{3+}>\left[\mathrm{Co}\left(\mathrm{NH}_{3}\right)_{5} \mathrm{Br}\right]^{2+}>$ $\left[\mathrm{Co}\left(\mathrm{NH}_{3}\right)_{5} \mathrm{Cl}\right]^{2+}$

with the other amines failing to cause the transition under 305 the $11 \mathrm{mM}$ salt and temperature ramp conditions used, and the DNA bending ranking is:

$$
\begin{aligned}
& \text { spermine }>\left[\mathrm{Co}\left(\mathrm{NH}_{3}\right)_{6}\right]^{3+}>(+)-[\mathrm{Co}(\text { en })]^{3+}>(-)-[\mathrm{Co}(\text { en })]^{3+} \\
& >\left[\mathrm{Co}\left(\mathrm{NH}_{3}\right)_{5}\left(\mathrm{H}_{2} \mathrm{O}\right)\right]^{3+}>\text { trans }-\left[\mathrm{Co}\left(\mathrm{NH}_{3}\right)_{4}\left(\mathrm{H}_{2} \mathrm{O}\right)_{2}\right]^{3+}> \\
& 310 \text { spermidine }
\end{aligned}
$$

with the other ammines having comparatively little effect. The most notable things about the above lists is that the rankings of the molecules varies with the structural effect 315 being investigated. There is a general trend of reducing efficacy with reducing charge (the aquo complexes will be deprotonated at $\mathrm{pH}=6.8$ ) but the key conclusion from this work is that the molecular interaction surfaces are important for determining how metal complexes affect DNA structure. 320 For example, the inability of the nitro and halo compounds to significantly bend the DNA (they are absent from the list above) leads to the conclusion that the bend-inducing binding mode requires deep penetration of the groove by hydrogen bonding donors. In accord with the hypothesis 
325 that a triangular face of amines facing the DNA is required to induce the $\mathrm{B} \rightarrow \mathrm{Z}$ transition, neither trans$\left[\mathrm{Co}\left(\mathrm{NH}_{3}\right)_{4}\left(\mathrm{H}_{2} \mathrm{O}\right)_{2}\right]^{3+}$ or $\left[\mathrm{Pt}\left(\mathrm{NH}_{3}\right)_{4}\right]^{2+},{ }^{26}$ are capable of inducing the $\mathrm{B} \rightarrow \mathrm{Z}$ transition (even in the absence of $\mathrm{NaCl}$ ). The other compounds' ranking are consistent with their 330 ability to face the DNA with NNN faces. ${ }^{24}$

\subsubsection{Metallo helicates}

A considerable amount of research in recent years has been focussed on the synthesis of supramolecular helicates with the purpose of having them interact with DNA to cause 335 conformational changes. The term helicate in this context refers to helical coordination arrays containing at least one metal centre. The ligands which surround the metal ions must contain multiple coordination sites and flexibility in order to wrap around in a helical fashion and must include 340 sufficient spacer groups to prevent adjacent binding domains binding to the same metal ion. The helicates may be 2,3 or 4 -stranded.

The simplest example of our helicate is the tris chelate complexes such as $\left[\mathrm{Ru}(\mathrm{phen})_{3}\right]^{2+}$ mentioned above. More 345 complicated examples of this type of compound involve the imine-based ligand systems ${ }^{27}$ (Fig. 2.2.5.1) synthesized by Hannon and co-workers. Depending on the metal and the ligands, they form double or triple 2-metal helicates with iron, copper, silver and nickel centres. The two metal 350 binding sites of each individual chelate are prevented from binding to the same metal centre by the phenylenes in the ligand whilst the methylene group allows sufficient flexibility to wrap around in a helical manner. ${ }^{27}$

The most studied of the imine dinuclear iron-centred 355 triple helicates has been shown to bind to DNA in the major groove and induce dramatic intra-molecular coiling. ${ }^{28}$ Induced $C D$ signals in the DNA and metal-ligand charge transfer region indicate that the helicate is binding in a single mode for helicate concentrations lower than 5 base 360 pairs: 1 helicate, and positive $L D$ signals for metal ligand charge transfer transitions show that the helicate is binding in an oriented non-random fashion. ${ }^{29,} 30$

Atomic force microscopy used in tapping mode showed that this helicate causes intramolecular supercoiling of free 365 linearised DNA (Fig. 2.2.5.2) which is in distinct contrast to the commonly observed DNA intermolecular condensation and aggregation mentioned above with e.g. hexammine cobalt. The location of the helicate binding site was investigated using a technique called nuclear Overhauser 370 effect spectroscopy (NOESY, see below for technique details). ${ }^{31}$ There were a number of cross-peaks in the resulting spectra which indicated contact between the helicate and the major groove of DNA which confirms that the helicate does indeed bind in the major groove. A later 375 study $^{30}$ using $C D$ and flow- $L D$ spectroscopies noted the difference in binding mode of each enantiomer. The conclusion was that the $\mathrm{M}$ enantiomer binds in the major groove whilst the $\mathrm{P}$ enantiomer may bind in the minor groove due to different complementarities of helicate-DNA 380 surfaces.

Recently, this tetracationic helicate has been shown in an $\mathrm{X}$-ray crystallography study to induce a junction with 3-fold symmetry made up of three oligonucleotides with the helicate residing in the central cavity. The cavity induced in 385 the DNA structure is a triangular shaped hydrophobic domain $^{28}$ formed by three double-strands of DNA that converge on one locality. This type of structure is unprecedented for a synthetic molecule but nicely illustrates how the symmetry possibilities afforded by 390 metallomolecules can be used to template DNA structures. Whether such structures could be formed in the presence of polynomic DNA remains to be seen.

The basic message from this particular recent example is that we have in no way exhausted the range of structures 395 that can be induced in DNA upon interaction with metallo systems. The challenge is invariably how to recognise that a new structure has been formed and to identify its nature and function.

\subsection{Intercalation between DNA base pairs}

400 DNA intercalation was defined by Mainwaring as the sandwiching of a molecule between two adjacent pairs of bases in the DNA double helix. ${ }^{32}$ Intercalating ligands are characterised by the possession of an extended electron deficient planar aromatic ring system. Upon binding, they 405 extend and unwind the deoxyribose-phosphate backbone and are stabilised by $\pi-\pi$ stacking interactions with the planar aromatic bases. $^{33}$ Intercalation also leads to hydrodynamic changes in the DNA due to the decrease in twisting between the base pair layers, the lengthening of the 410 DNA itself, the stiffening of the helix, and the decrease in mass per unit length. These effects are fully reversible upon removal of the intercalator as long as the DNA duplex structure is not destroyed by the process of removal. Lerman showed that a bound intercalator lies in a plane 415 perpendicular to the helix axis, and that the perpendicularity of the base pairs to the helix is not significantly altered. ${ }^{34}$

Thus for a metal complex to be an intercalator it must either be planar or have an extended planar component which can slot between base pairs. In 1978 Lippard 420 published details of several planar platinum-based metallointercalators (Fig. 2.3.1) whilst seeking to understand the binding modes of the genre of platinum-based anti-tumour agents that were beginning to emerge. ${ }^{15}$ Another class of potential metallo intercalators is cationic porphyrins which 425 combine readily with metal centres in their central cavity and exhibit a strong binding affinity for DNA. There have been three binding methods described in the literature for such molecules $\left({ }^{\text {references within }}{ }^{35}\right.$ ): self-induced external autoaggregation along the DNA helix axis, binding in either the 430 major or minor groove of DNA and intercalation between base pairs. However, intercalation only occurs if the metal lies in the same plane as the porphyrin ring.

The ability of porphyrin compounds to bind to DNA has been used to bring other moieties into close proximity to 435 DNA by using a porphyrin core as a molecular anchor. These moieties can be designed to increase binding affinity or to include chemical functionalities which can modify DNA structure via an independent method. $\mathrm{Cu}^{2+}$ compounds have been shown to operate as DNA cleavage agents ${ }^{36}$ and 440 recently dimetallo copper-bipyridyl porphyrins ${ }^{35}$ have been shown to bind to DNA by intercalation and external 
association and cleave DNA under certain experimental conditions. These molecules are formed by combining a copper-porphyrin ring which anchors the complex to DNA 445 with copper-bipyridinium which hydrolyses phosphodiester bonds (Fig. 2.3.2). This rather dramatic structural effect on DNA is potentially useful either in the molecular biology laboratory or in drug design.

The less direct method of achieving intercalation of a 450 metallo system is illustrated by dipyridophenanzinebi(phenanthroline) ruthenium(II), $\left[\mathrm{Ru}(\text { phen) })_{2} \mathrm{dppz}\right]^{2+37}$ (Fig. 2.3.3) where effectively a phenanthroline of $\left[\mathrm{Ru}(\mathrm{phen})_{3}\right]^{2+}$ (Fig. 2.2.2.2) is extended by a planar aromatic group which prefers an intercalated binding mode. Its binding to DNA ${ }_{455}$ causes an elongation of the rod-like DNA molecule consistent with classical intercalation. ${ }^{37}$

\section{Detecting DNA structure changes}

The above discussion demonstrates that metal-containing molecules can have dramatic effects on DNA structure. 460 However, how does one conclude that this is the case for a new molecule and determine what the effect is? There are various ways of measuring the deviation of the helix backbone from a straight line and various measures of DNA base displacement from the canonical B-DNA positions. 465 Such measures really rely on having atomic level structural information from nuclear magnetic resonance spectroscopy (NMR), X-ray crystallography or molecular modelling studies and are valuable when such data are available. Other techniques provide less detailed information but are usually 470 easier to implement.

Given below is a desciption of the main techniques used to detect and analyse DNA structural changes in this context, alongside examples of how these techniques can be used. Note that the examples given are not intended to 475 provide indepth knowldege on all possible occasions where the technique may be adopted, but rather to give a variety of different applications where it has already been shown to be of use.

\subsection{Nuclear magnetic resonance spectroscopy}

${ }_{480}$ NMR spectroscopy is a powerful technique which enables geometrical details of the structure of DNA on an atomic level in solution to be elucidated. In addition, changes in chemical shifts induced by temperature or concentration variation can provide information about DNA-complex 485 association.

This technique relies on a property of nuclei known as spin which is an intrinsic quantum physical property of a nucleus and has no direct analogue in the macroscopic world, but behaves like an angular momentum. When a 490 nucleus is placed in an external magnetic field, its spin magnetic moment moves around the direction of the field at a frequency termed the Larmor frequency which is directly proportional to the strength of the magnetic field experienced by the particle. Although nuclear spin has only 495 a negligible effect on the chemical and physical properties of atoms, the energy levels or precession frequencies adopted by nuclei in different spin states are extremely sensitive to the individual chemical environment of a nucleus. Thus if one can measure the energy level gaps or 500 precession frequencies one can in principle determine the local chemical environment of a nucleus of interest.

A radiofrequency pulse is applied to the system causing all the spin polarisations to rotate by $90 \mathrm{When}$ the pulse is switched off, a net spin polarisation exists perpendicular to 505 the external field and since each individual spin precesses, the bulk magnetic moment does as well. The precession frequency of this bulk moment is the same as the Larmor frequency and it decays or 'relaxes' over time approximately exponentially and in an oscillating manner. 510 An electric current is induced from this alternating magnetic field in a wire coil and is referred to as the NMR signal or free-induction decay.

NMR delivers information on a submolecular scale to a high resolution because of the inhomogeneous distribution 515 of electrons in molecules which results in nuclei at different points within the molecule being subject to slightly different magnetic fields. Thus the Larmor frequency depends on the local chemical environment and leads to different nuclei having different chemical shifts. This is displayed as a 520 resonance peak at a particular parts per million value on an (already Fourier-transformed) NMR spectrum. With metallo systems binding to DNA, the extent of changes in chemical shifts for DNA protons upon ligand binding have often been used as an indication of where the ligand is located: more 525 shift equals more perturbation hence indicating the binding site. However, one must take care as this simplistic approach is really predicated on there being little or no change to the DNA structure upon ligand binding. A better approach is to use a range of alternative NMR techniques 530 which give through bond or through space distances between atoms.

Nuclear Overhauser effect spectroscopy (NOESY) provides the ability to plot the through space connectivities between atoms with the strength of the signal observed 535 depending on their distance. NOESY couplings arise because the use of a small radio frequency field at the Larmor frequency of one nuclear spin results in an enhancement of the magnetisation of some of the nonradiated nuclear spins. ${ }^{31}$ Thus one can identify whether 540 given atoms are near each other in 3-dimensional structures. The NOESY data gives certain inter-atomic distances, which can be used as restraints in molecular modelling and one can therefore sometimes determine 3D structures.

NOESY data cannot be used to analyse the structure of a 545 long DNA molecule as the peak-assignments on the resulting spectra becomes prohibitively complicated as the chemical shifts for various atoms overlap extensively. It can, however, be used to study oligonucleotides and molecules binding to oligonucleotides. An example of this 550 is the use of molecular dynamics restraints obtained from NOESY data to determine features of the iron helicate mentioned above with a DNA decamer. ${ }^{38}$ The accurate interpretation of NOESY spectra, or related techniques such as correlation spectroscopy $(\mathrm{COSY})^{31}$ and rotating frame 555 Ovehauser enhancement spectroscopy (ROESY) ${ }^{31}$ rely on 
molecular modelling to elucidate the correct molecular structure between multiple possible arrangements.

One application of NOESY was to show that the X-ray detected DNA conformational changes induced by cis560 platin $^{15}$ were consistent with the behaviour observed when in solution. Assignment of the proton resonances were used to inform molecular dynamics simulations, from which was elucidated proton-proton and proton-phosphorus coupling constants. Analysis of these constants suggested a 565 conformational change of one deoxyribose moiety leading to a kink in the DNA oligonucleotide. This is one of many examples of how the atomic-resolution information gathered by NMR can be used to provide valuable insights on the structural behaviour of DNA under the influence of 570 metallomolecules.

\subsection{X-ray crystallography}

X-ray crystallography relies on Bragg's law which states that an X-ray beam reflecting from a surface layer of a crystalline material travels a shorter distance than those 575 reflected by the inner layers. The beams are in-phase if the difference in these distances is an integer value of wavelengths of the incident radiation and hence produces an enhanced signal compared to when they are out-of-phase. Bragg suggested that the differences in distances relies upon 580 the angle of incidence of the beam so that by changing this angle, a diffraction pattern can be built up which can then be Fourier-transformed and interpreted to give atomic-level structural information. ${ }^{39}$ It is extremely attractive to have such data for metal complex-DNA systems, however, the 585 challenge is that it is necessary to crystallise the sample to get such data. This is often not a trivial exercise, and always involves carefully chosen short DNA sequences. The biological significance of this structure is not clear.

It is important to note when studying and utilising the 590 literature, particularly with X-ray and NMR data where the end result is a beautiful picture of the DNA-ligand system, that data determined for oligonucleotide systems are not necessarily applicable for pieces of DNA of the length of a gene or a genome. A simple illustration is provided by the 595 three-way junction structure discussed above which is induced in oligonucleotides by a tetracationic dimetallo helicate molecule: it requires the appropriate base pairing to be available and the DNA strands to rearrange themselves from the standard form of B-DNA. There is also the fact 600 that solid state crystalline structures derived from crystallisation buffers do not necessarily bear any relationship to those adopted in biological systems.

\subsection{Gel electrophoresis}

Persistence length is a useful concept when considering 605 polymeric pieces of DNA. A working definition for the persistence length (Fig. 3.3.1) of a piece of DNA is taken to be the average length of DNA required for the helix backbone to bend 1 radian $\left(=180 / \pi=57.3^{\circ}\right)$. Typical B-DNA has a persistence length of about 150 base pairs. When the ${ }_{610}$ DNA is bent or made more flexible, this is reduced. Thus this parameter gives a measure of bending or flexibility of DNA. For example at the cis-platin binding site (Fig.
2.2.1.2), the persistence length is reduced to just a few base pairs. There is no really simple way to measure this fairly 615 simple parameter. One method is to use AFM pictures of samples of DNA with and without the ligand of interest. ${ }^{29}$ This is tedious and dependent on sampling methods to get a clear indication of what is happening. An alternative approach is to measure the changes in mobility of DNA in 620 gels as a function of ligand loading on DNA.

Gel electrophoresis involves application of an electric field across the length of the gel causing the migration of charged molecules toward the oppositely charged electrode. At neutral $\mathrm{pH}$, DNA is negatively charged so moves through 625 the gel from cathode towards the anode. The electrophoretic mobility of a piece of DNA on a gel is dependent on its flexibility, size and charge.

If, when a molecule binds to DNA it affects the size or shape of the DNA, then it will affect its electrophoretic 630 mobility. For example, an intercalator is expected to unwind the DNA, which lengthens and stiffens it. Using circular DNA of known supercoiling ${ }^{40}$ the degree of unwinding per ligand bound can be determined. Whether the binding event is consistent with intercalation can then be determined. 635 Ethidium bromide, the archetypical intercalator, unwinds DNA by an average of $26^{\circ}$ per ligand (which is $10^{\circ}$ less than the base-base twist in canonical B-DNA). The degree of unwinding induced by a given metal complex has been shown to indicate which binding mode it adopts: ${ }^{41}$ mono640 adduct platinum (II) complexes generally afford little unwinding, whereas bifunctional adducts such as cis-platin (unwinding angle $13^{\circ}$ )have more effect, though significantly less than that of an intercalator (Fig. 3.3.2). ${ }^{42}$

An alternative application of gel electrophoreis has been ${ }_{645}$ described by Carle et al. ${ }^{43}$ They used it as a method of fractionating DNA into size based fractions by applying a series of orthogonal electric fields on a gel. By altering the duration of the electric field pulses in each direction, a greater accuracy in the DNA separation for a given size 650 range can be achieved. The technique can also be used to check for DNA charge reversal ${ }^{44}$ which can occur when DNA is resolubilised in the presence of multivalent cations. Charge reversal is said to have occurred if the DNA migrates towards the cathode terminal.

\section{3.4 Circular dichroism}

Circular dichroism (CD), the difference in absorption of left and right circularly polarised light, ${ }^{45}$ is uniquely sensitive to chirality or helicity of molecules. Thus DNA CD depends on the arrangement of the DNA bases and if this is changed,

660 then the $C D$ spectrum changes. The source of the chirality in DNA is the ribose sugar backbone of DNA, however, sugar $C D$ signals are below $190 \mathrm{~nm}$, so essentially inaccessible in laboratory-based CD machines. Between 190 and $300 \mathrm{~nm}$, there is a DNA signal observed from the 665 coupling of the stacked planar bases, which adopt chiral (helical arrangement in space) structures. $C D$ can be used to probe DNA structures as illustrated in Fig. 3.4.1 ${ }^{46}$ since right-handed B-DNA and the left-handed Z-DNA, for example, have quite different $C D$ spectra (not mirror images 670 of one another since the structures are not enantiomeric). In 
the context of this article, the effect of DNA on the $C D$ of bound ligands can be a useful probe technique. Achiral molecules in solution produce no net intrinsic $C D$ signal, however, if they bind to a chiral molecule such as DNA this 675 can result in an induced $C D$ (ICD) signal. Sometimes this can be used structurally but more often it gives a method of estimating binding strengths between the DNA and ligand, or the DNA base:ligand ratio. An example of this is given in Fig. 3.4.2. ${ }^{47}$

${ }_{680}$ A useful assay developed by Jaroslav Malina (personal communication) to determine in which groove a metal complex binds is to probe the displacement of the ligand by the major groove binding $\left[\mathrm{Co}\left(\mathrm{NH}_{3}\right)_{6}\right]^{3+}$ (or conversely). With poly $[\mathrm{d}(\mathrm{G}-\mathrm{C})]_{2}$, $\left[\mathrm{Co}\left(\mathrm{NH}_{3}\right)_{6}\right]^{3+}$ induces Z-DNA. When it 685 displaces a ligand and binds, the $C D$ changes sign at $290 \mathrm{~nm}$ from the positive signal for B-DNA to negative as illustrated in Fig. 3.4.3. ${ }^{48}$ In other cases, where there is no competition between the ligand binding sites, there is no induction of Z-DNA.

\section{3.5 Linear dichroism}

Linear dichroism $(L D)$ is a technique that may be used with systems that are either intrinsically oriented or are oriented during the experiment; it is the difference in absorption of light linearly polarised parallel and perpendicular to an 695 orientation axis. ${ }^{45}$ In the case of long DNA molecules (>250 base pairs), flow orientation such as that induced by a Couette flow cell (Fig. 3.5.1) ${ }^{49}$ is an effective orientation technique. The speed of the revolving chamber must be such that it is not causing turbulent flow but is still strong enough 700 to orientate the sample in question, in this case DNA. DNA base pairs are approximately perpendicular to the DNA helix axis and their in-plane $\pi-\pi^{*}$ transitions give a negative $L D$ signal under absorbance bands.

If the DNA is bent or kinked, as occurs with adding the 705 above mentioned iron triple helicate, the DNA LD signal magnitude decreases as illustrated (Fig. 3.5.2). The bend induced per bound helicate can be determined. ${ }^{29} L D$ can also be used to probe the binding of molecules to DNA since small molecules will only produce a flow $L D$ signal if 710 they are oriented due to binding in a specific regular manner to the long DNA. Fig. 3.5.2 shows an example of DNA bending (as viewed by the loss of $L D$ at $260 \mathrm{~nm}$ upon addition of ligand) and also the orientation of the ligand itself in the ligand charge transfer region at $550 \mathrm{~nm} .^{48}$

715

\subsection{Molecular dynamics simulations}

Molecular dynamics simulations provide an atomicresolution depiction of molecular systems by the application of Newton's equations of motion to generate successive 720 configurations of a system which combine to give a trajectory. ${ }^{50}$ In biomolecular science we can obtain both physico-chemical properties through statistical sampling of a system in equilibrium and an understanding of pathways and mechanisms of action by following individual particle

725 motions. Comparing simulation results with experimental data is essential because the experimental data can be used to validate the simulations and the simulations may help to interpret the experiments correctly or guide future work. The method is limited, however, by the necessity for an 730 accurate description of the experimental situation and the computational power needed to accurately describe the forces and motions involved. Concessions have to be made, in order to run simulations on a reasonable timescale, such as limiting the number of degrees of freedom, the length of 735 time simulated, the system size and the accuracy of the relevant force fields. Relevant controllable parameters in such experiments include the temperature, pressure, volume of periodic box, and of course the total length of the simulation. Most DNA simulations are on relatively short

740 DNA sequences which precludes observation of any long range effects.

Khalid et al. ${ }^{51}$ have demonstrated the usefulness of molecular dynamics by analysing the molecular interactions that lead to binding and subsequent DNA structure control 745 by the metallo helicate illustrated in Fig. 2.2.5.1. They discovered by simulating over an array of parameters that the helicate-DNA interactions that promote DNA coiling are dominated not by the cationic charge of the molecule (as in the case of DNA condensation into toroids) but by short750 range interactions.

Haworth et al. also found molecular modelling useful as noted above in determining the binding modes of cobalt ammine complexes and understanding how these metal complexes influence DNA structural changes such as the B 755 to $\mathrm{Z}$ transition and DNA condensation. ${ }^{52}$

All-atom molecular modelling as described above is limited by the time and computational power required to perform the simulation - particularly in relation to the volume of the system and the total simulation time. One of 760 the ways to extend the usefulness of MD is to reduce the number of degrees of freedom in a technique known as coarse-grain modelling. ${ }^{53}$ Here, a number of atoms are mapped onto coarse-grain beads thus eliminating fine atomatom interaction details and yielding a simulation that 765 requires fewer resources and runs faster than an all-atom equivalent. However, at this point in time it is very difficult to find effective merging of molecular dynamics and course graining for DNA systems.

\section{Conclusions}

770 The most important molecule in any cell is DNA and structural changes induced by foreign bodies such as metallomolecules are of huge significance in the fields of molecular biology and medicine. Since the double-helical structure of B-DNA was recognised in the $1950 \mathrm{~s},{ }^{3}$ many 775 synthetic molecules have been shown in bind to DNA in differing binding modes promoting a variety of structural changes in the DNA. Whilst some molecules such as cisplatin, a leading chemotherapy agent, have been found to be DNA-targeting (a long time after its introduction into the 780 drug market in 1978), other molecules such as an array of double and triple metallo-helicates ${ }^{30}$ have been specifically designed with DNA as the target.

The binding modes of metallomolecules can be divided into an external association with DNA, groove binding in 
785 either the major or minor groove and intercalation between DNA base pairs. The precise binding mode and consequent DNA structural changes can be analysed using a range of experimental techniques, such as NMR, X-ray crystallography, gel electrophoresis, circular dichroism, 790 linear dichroism and modelling using molecular dynamics. Each of these techniques has different advantages and different limitations, such as the need to generate crystals for X-ray crystallography or the necessity for molecular dynamics simulations to accurately represent the in vivo 795 situation. Despite these restrictions they have proved reliable and accurate techniques when used appropriately for discerning the exact nature of DNA-metallomolecule interactions.

Synthetic metallomolecules have been proven to have a 800 range of dramatic effects on the structure of DNA. As synthetic and analytical chemistry continues to evolve, metallomolecules have a bright future both in aiding our understanding of the structure and function of DNA and also as potential diagnostic or therapeutic agents.

\section{Biographies:}

Adair Richards was educated at the University of Warwick and received his BSc in Mathematics in 2003 and then attained a distinction in his MSc in Mathematical Biology and Biophysical Chemistry in 2004. He is now studying for 810 his $\mathrm{PhD}$, also at the University of Warwick, under the supervision of Albert Bolhuis and Alison Rodger in collaboration with Mike Hannon of the University of Birmingham. His project involves researching the interactions of supramolecular metallomolecules with 815 biological systems at the sub-cellular level.

Alison Rodger graduated from Sydney University with the University Medal for Theoretical Chemistry in 1982. She completed her $\mathrm{PhD}$ in 1985 whereupon she took up a 820 Beatrice Dale Research Fellowship at Newnham College, Cambridge together with an Overseas Scholarship from the Royal Commission for the Exhibition of 1851. She next spent six years in Oxford at St. Catherine's and St. Hilda's Colleges where she held a Glasstone Research Fellowship, 825 moving to Warwick in 1994. In 2005 she became Professor of Biophysical Chemistry. Her laboratory focuses on developing and implementing UV/visible spectroscopic techniques (including circular and linear dichroism) to study the structure and function of biomacromolecules.

\section{${ }_{830}$ References}

1. F. Miescher, Med. Chem. Unters., 1871, 4, 441.

2. E. Chargaff, Experientia, 1950, 6, 201.

3. J. D. Watson, F.H.C. Crick, Nature, 1953, 171, 964.

4. W. Humphrey, A. Dalke, K. Schulten, J. Molec. Graphics, 1996, 835 14, 33.

5. W. Guschlbauer, Nucleic Acid Structure, Springer-Verlag New York Inc., New York, 1976.

6. S. Neidle, DNA Structure and Recognition, OUP, 1994.

7. R. Holliday, Genet. Res., 1964, 5, 282.
840 8. G. L. Eichhorn, Y.A. Shin, J. Am. Chem. Soc., 1968, 90, 7323.

9. E. F. Gale, E. Cundliffe, P.E. Reynolds, M.H. Richmond, M.J. Waring, The Molecular Basis of Antibiotic Action, 2nd edn., John Wiley \& Sons Ltd., 1981.

10. D. Goodsell, R.E. Dicherson, J. Med. Chem., 1986, $29,727$.

845 11. D. Z. M. Coggan, P.J. Baters, I.S. Haworth, A. Rodger, A.J. Robinson, Inorg. Chem., 1999, 38, 4486.

12. R. Marrington, T. R. Dafforn, D. J. Halsall and A. Rodger, Biophysical Journal, 2004, 87, 2002.

13. B. Rosenberg, L. Van Camp, T. Krigas, Nature, 1965, 205, 698. 850 14. T. Boulikas, M. Vougiouka, Oncology Reports, 2003, 10, 1663.

15. J. H. J. den Hartog, C. Altona, J-C. Chottard, J-P. Girault, J-Y. Lallemand, F.A.A.M. de Leeuw, A.T.M. Marcelis, J. Reedijk, Nucleic Acids Res., 1982, 10, 4715.

16. S. E. Sherman, D. Gibson, A.H.J. Wang, S.J. Lippard, J. Am.

$855 \quad$ Chem. Soc., 1988, 110, 7368.

17. Y. Zou, B. Van Houten, N. Farrell, Biochemistry, 1993, 32, 9632.

18. C. Manzotti, G. Pratesi, E. Menta, R. Di Domenico, E. Cavalletti, H.H. Fiebig, L.R. Kelland, N. Farrell, D. Polizzi, R. Supino, G. Pezzoni, F. Zunino, Clin. Cancer. Res., 2000, 6, 2626.

860 19. M. J. Clarke, F. Zhu, D.R. Frasca, Chem. Rev., 1999, 99, 2511.

20. E. Alessio, E. Iengo, S. Zorzet, A. Bergamo, M. Coluccia, A. Boccarelli, G. Sava, J. Inorg. Chem., 2000, 79, 173.

21. C. Hiort, B. Norden, A. Rodger, J. Am. Chem. Soc., 1990, 112, 1971.

865 22. D. M. Loprete, K.A. Hartman, Biochemistry, 1993, 32, 4077.

23. H. Tabor, Biochemistry, 1962, 1, 496.

24. M. H. A. Parkinson, M. Hall, K. J. Sanders, A. Rodger, Phys. Chem. Chem. Phys., 2000, 2, 5469.

25. R. V. Gessner, G. J. Quigley, A. H. J. Wang, G. A. V. D. Marcel,

870 J. H. V. Boom, A. Rich, Biochemistry, 1985, 24, 237.

26. A. Rodger, A. Parkinson, S. Best, Eur. J. Inorg. Chem., 2001, 9, 2311.

27. M. J. Hannon, C.L. Painting, A. Jackson, J. Hamblin, W. Errington, Chem. Commun., 1997, 9, 1807.

875 28. A. Oleksi, A.G. Blanco, R. Boer, I. Uson, J. Aymami, A. Rodger, M.J. Hannon, M. Coll, Agnew. Chem. Intl. Ed., 2006, 45, 1227.

29. M. J. Hannon, V. Moreno, M.J. Prieto, E. Molderheim, E. Sletten, I. Meistermann, C.J. Isaac, K.J. Sanders, A. Rodger, Angew.

$880 \quad$ Chem. Intl. Ed., 2001, 40, 879.

30. I. Meistermann, V. Moreno, M.J. Prieto, E. Moldrheim, E. Sletten, S. Khalid, P.M. Rodger, J.C. Peberdy, C.J. Isaac, A. Rodger, M.J. Hannon, Proc. Natl. Acad. Sci., 2002, 99, 5069.

885 31. M. H. Levitt, Spin dynamics: Basics of Nuclear Magnetic Resonance, J. Wiley \& Sons Ltd, Chichester, 2001.

32. W. I. P. Mainwaring, J.H. Parish, J.D. Pickering, N.H. Mann, Nucleic Acid Biochemistry and Molecular Biology, Blackwell Scientific Publications, 1982.

890 33. L. S. Lerman, J. Mol. Biol., 1961, 3, 18.

34. L. S. Lerman, Proc. Natl. Acad. Sci., 1963, 49, 94.

35. M. Laine, F. Richards, E. Tarnaud, C. Bied-Charreton, C. Verchere-Beaur, J. Biol. Inorg. Chem., 2004, 9, 550.

36. J. Liu, T. Zhang, T. Lu, L. Qu, H. Zhou, Q. Zhang, L. Li, J. Inorg. $895 \quad$ Biochem., 2002, 91, 269. 
37. I. Haq, P. Lincoln, D. Suh, B. Norden, B.Z. Chowdhry, J.B. Chaires, J. Am. Chem. Soc., 1995, 117, 4788.

38. E. Molderheim, M.J. Hannon, I. Meistermann, A. Rodger, E. Sletten, J. Biol. Inorg. Chem., 2002, 7, 770.

900 39. W. L. Bragg, Proc. Cambridge Philos. Soc., 1913, 17, 43.

40. M. H. Ushay, T.D. Tullis, S.J. Lippard, Biochemistry, 1981, 20, 3744.

41. U. Bierbach, Y. Qu, T.W. Hambley, J. Peroutka, H.L. Nguyen, M. Doedee, N. Farrell, Inorganic Chemistry, 1999, 38, 3535.

905 42. M. J. Browning, Unpublished work, University of Warwick, 2005.

43. G. F. Carle, M.V. Olson, Nucleic Acids Research, 1984, 12, 5647.

44. J. Pelta, F. Liovolant, J-L. Sikorav, J. Bio. Chem., 1996, 271, 5656.

45. A. Rodger, B. Norden, Circular Dichroism and Linear Dichroism, OUP, 1997.

910 46. A. Parkinson, University of Warwick, 1998.

47. A. Rodger, K.K. Patel, K.J. Sanders, M. Datt, C. Sacht, M.J. Hannon, Dalton Trans., 2002, 3656.

48. J. Peberdy, University of Warwick, 2006.

49. W. S. Brey, Physical Chemistry and its Biological Applications, 915 Academic Press Inc., 1978

50. A. Rodger, H.C. Latham, P. Wormell, A. Parkinson, M.J. Ismail, K.J. Sanders, Enantiomer, 1998, 3, 395.

51. S. Khalid, M.J. Hannon, A. Rodger, P.M. Rodger, Chem. Eur. J., 2006, 12, 3493.

920 52. A. Rodger, K.J. Sanders, M.J. Hannon, I. Meistermann, A. Parkinson, D.S. Vidler, I.S. Haworth, Chirality, 2000, 12, 221.

53. B. J. Baschnagel, K., Doruker, P., Gusev, A.A., Hahn, O., Kremer, K., Mattice, W.L., Muller-Plathe, F., Murat, M., Paul, W., Santos, S., Suter, U.W., Tries, V., Adv. Polym. Sci., 2000, 152, 41. 


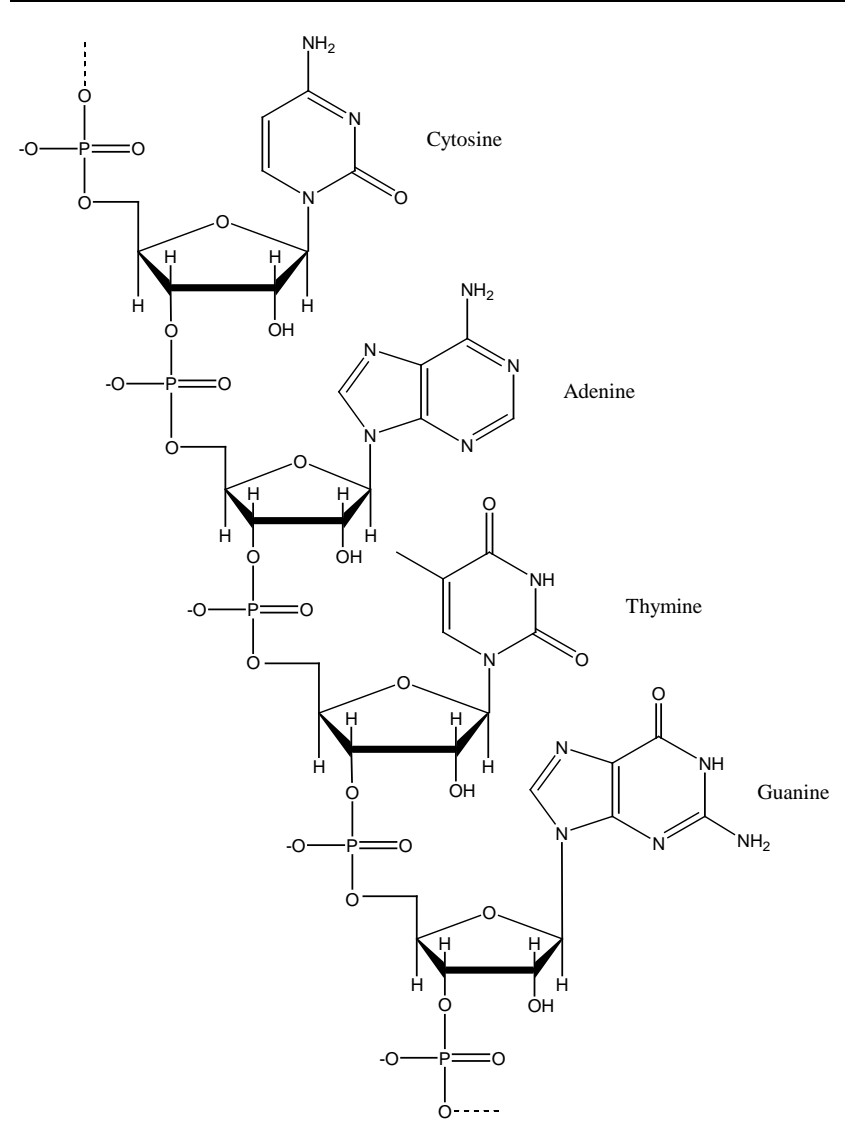

Fig. 1.1 The four DNA bases showing their connectivity to the phosphate-sugar backbone in DNA.

On a separate file.

Fig. 1.2 Schematic representation and space-filling model of B-DNA. (Created using VMD4)
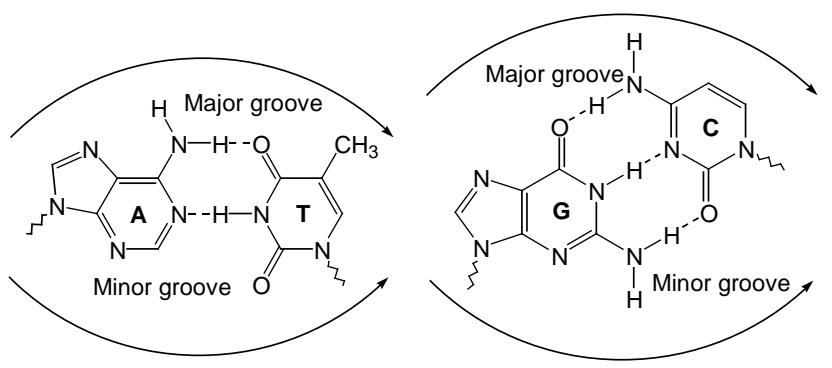

Fig. 1.3 Adenine-Thymine and Guanine-Cytosine base pairs showing the minor and major grooves. The wiggly bonds indicate the links to the sugar backbone.<smiles>CN1CCN(c2ccc3nc(-c4ccc5nc(-c6ccc(O)cc6)[nH]c5c4)[nH]c3c2)CC1</smiles>

Fig. 2.2.1 Chemical structure of a typical minor groove binder Hoechst 33258. 
<smiles>N[PH](N)(Cl)Cl</smiles>

Fig. 2.2.1.1 Chemical structure of cis-platin.

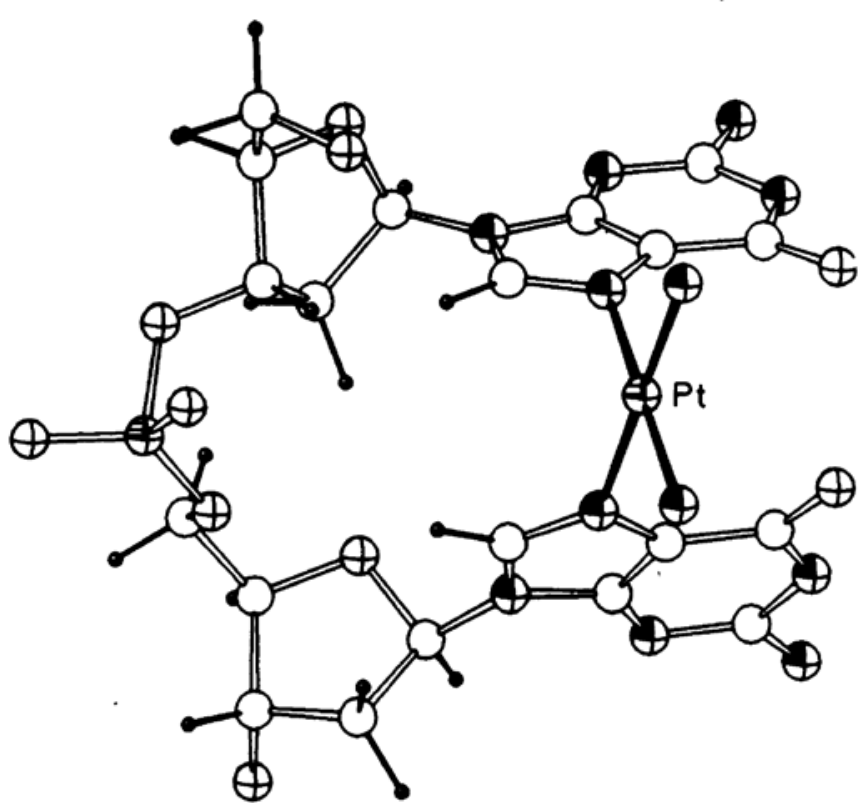

Fig. 2.2.1.2 DNA kinking induced by cis-platin binding. ${ }^{15}$

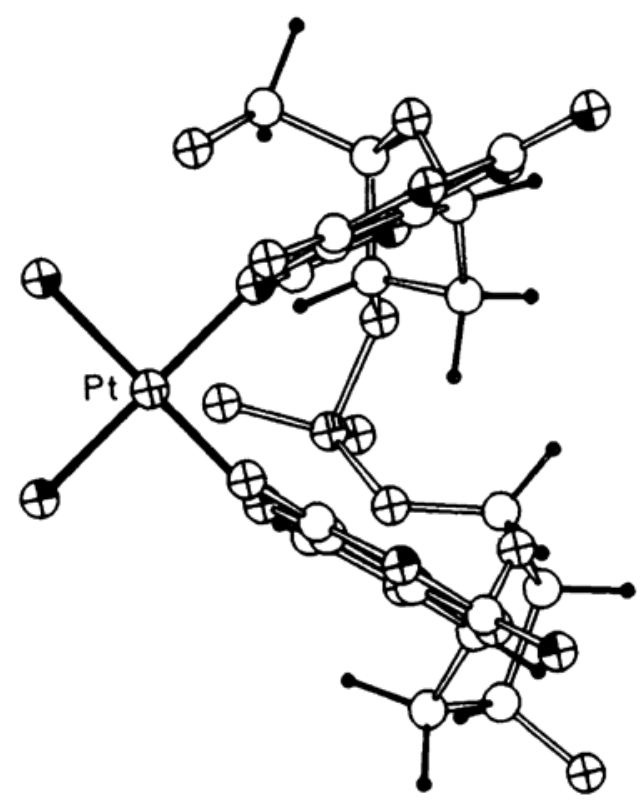

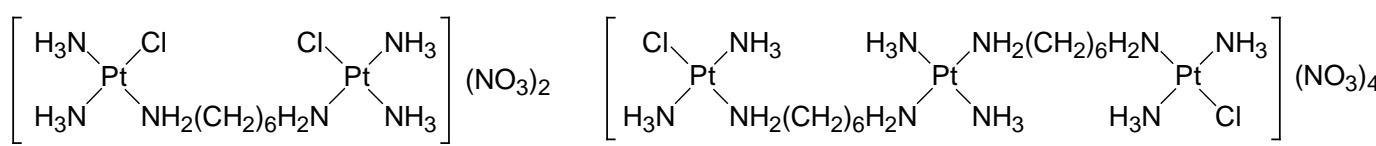

Fig. 2.2.1.3 $\left.\left[\text { cis-PtCl }\left(\mathrm{NH}_{3}\right)_{2}\right\}_{2} \mathrm{H}_{2} \mathrm{~N}\left(\mathrm{CH}_{2}\right)_{6} \mathrm{NH}_{2}\right] \mathrm{Cl}_{2}$ and BBR $3464 .{ }^{18}$

$\left[\begin{array}{ccc}\mathrm{DMSO} & \mathrm{Cl} \\ \mathrm{Cl} & \mathrm{Ru}^{-} & -\mathrm{Cl} \\ \mathrm{Cl} & \mathrm{Cl} & \mathrm{Im}\end{array}\right]^{-} \mathrm{ImH}^{+}$

Fig. 2.2.2.1 ImH[trans-RuCl4(DMSO)Im]. ${ }^{24}$ 

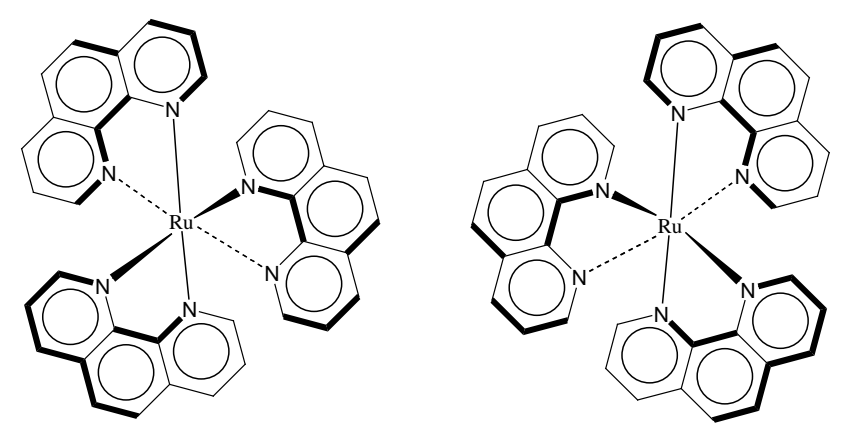

Fig. 2.2.2.2 The enantiomers of $\left[\mathrm{Ru}(\mathrm{phen})_{3}\right]^{2+}: \Lambda$ on left and $\Delta$ on right.<smiles>C(=N/c1ccc(Cc2ccc(/N=C/c3ccccn3)cc2)cc1)\c1ccccn1</smiles>

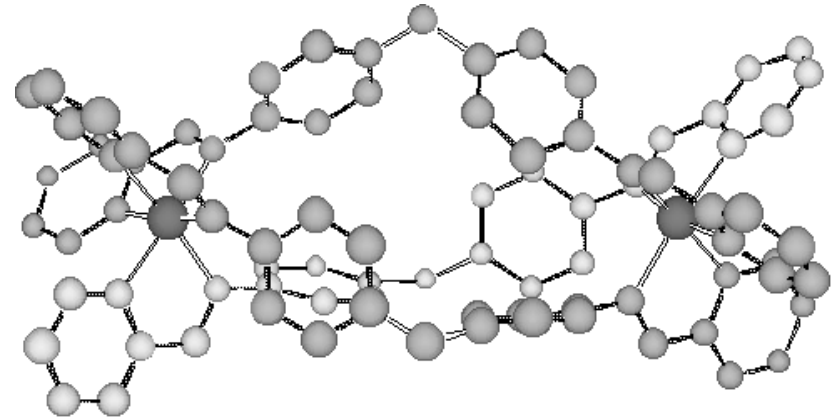

Fig. 2.2.5.1 Immine based ligand used to bind metal co-factors such as $\mathrm{Fe}^{2+}$ to form a helicate. ${ }^{27}$

On a separate file

Fig. 2.2.5.2 AFM image of helicate inducing intramolecular DNA supercoiling. ${ }^{28}$

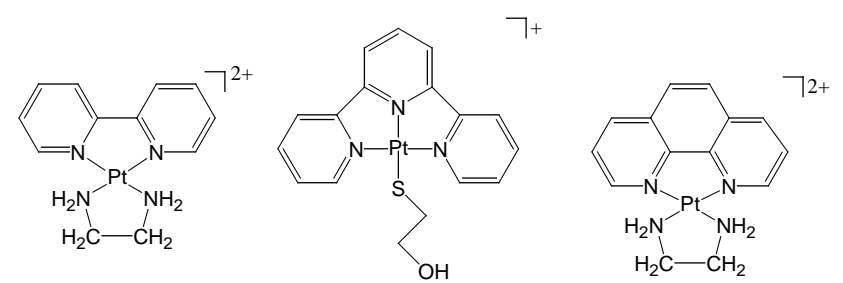

Fig. 2.3.1 Platinum complexes [Pt(bipy)(en) $]^{2+}$, [Pt(terpy)(HET) $]^{+}$and $[\mathrm{Pt}(\mathrm{o}-\mathrm{phen})(\mathrm{en})]^{2+}{ }^{2}{ }^{2}$ 


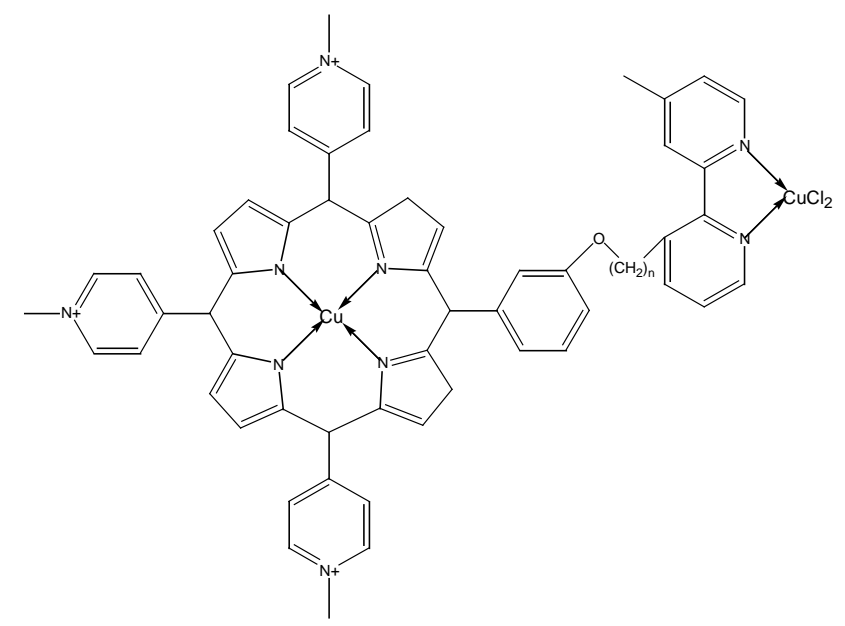

Fig. 2.3.2 3-[Cu-bpy-( $\left.\left(\mathrm{CH}_{2}\right) \mathrm{n}\right]-\mathrm{Cu}-\mathrm{MMPyP}{ }^{35}$

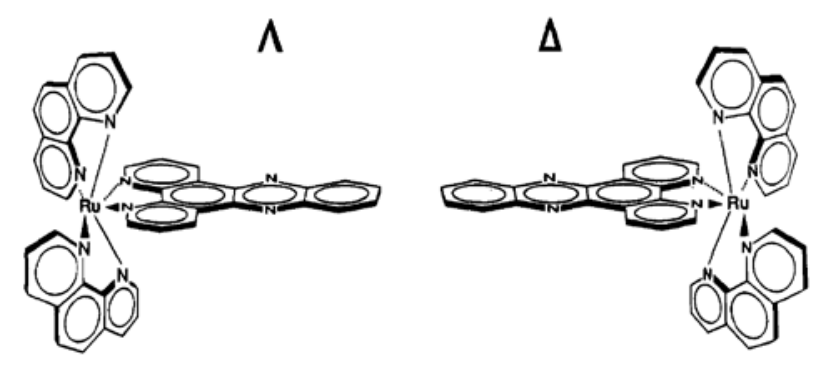

Fig. 2.3.3 The enantiomers of $\left[\mathrm{Ru}(\mathrm{phen})_{2} \mathrm{dppz}\right]^{2+}{ }^{37}$

\section{On a separate file}

Fig. 3.3.1 Persistence length (p) can be thought of as the minimum length of DNA required such that the tangents to the helix axis form an angle of 1 radian.

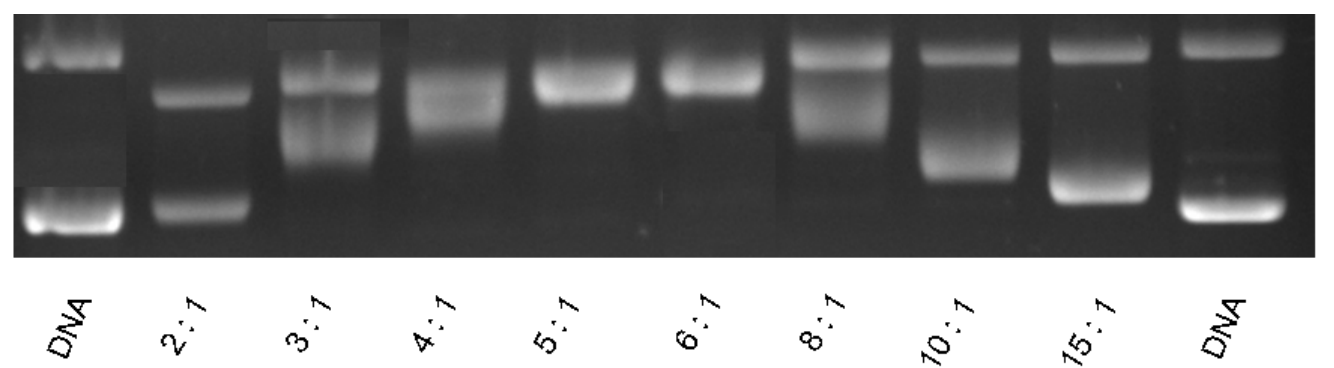

Relaxed

Super-coiled

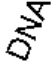

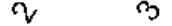
$\ddot{s} \dot{0}$
$0^{\circ}$

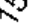

Fig. 3.3.2 Gel image of pBR322 DNA treated with cis-platin in DNA base:ligand ratios as indicated in the figure. The negatively supercoiled DNA sample has a small population of relaxed DNA. At 6:1 ratio both bands co-migrate; at higher ratios the DNA is being positively supercoiled. ${ }^{42}$ 

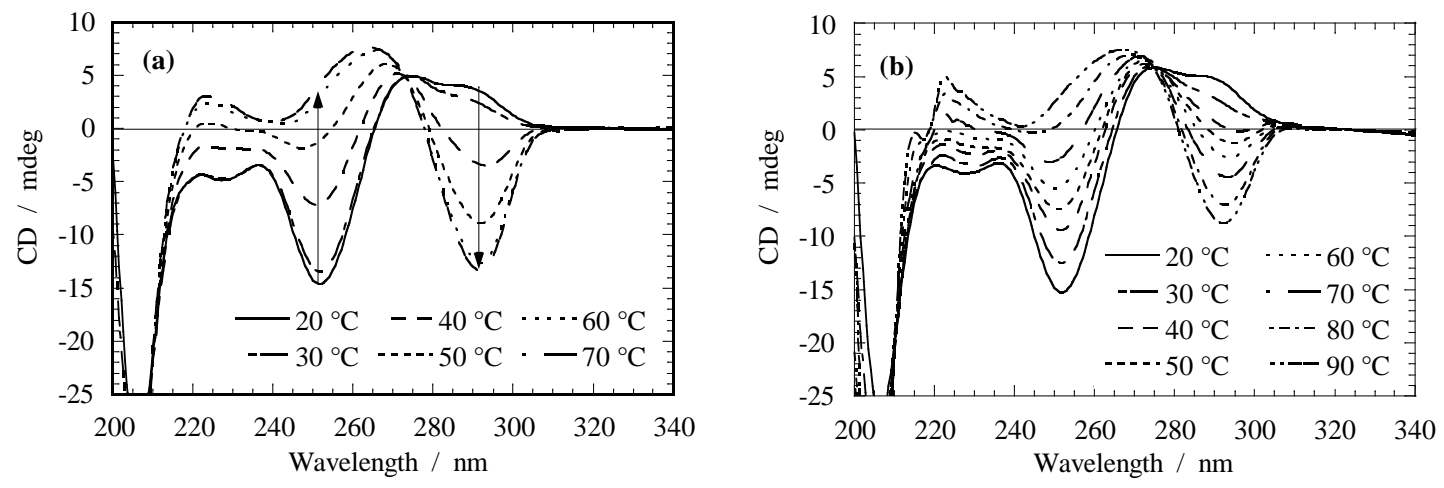

Fig. 3.4.1 $C D$ spectra of $[\text { poly }(\mathrm{dG}-\mathrm{dC})]_{2}$ as a function of temperature in the presence of (a) spermine $(5 \mu \mathrm{M}$ and $10 \mathrm{mM} \mathrm{NaCl})$, $90 \mu \mathrm{M}$ DNA and (b) $\left[\mathrm{Co}\left(\mathrm{NH}_{3}\right)_{6}\right]^{3+}(5 \mu \mathrm{M}$ and $10 \mathrm{mM} \mathrm{NaCl}), 100 \mu \mathrm{M}$ DNA. Arrows in (a) indicate direction of change in the CD spectra as the $\mathrm{B}$ to $\mathrm{Z}$ transition progresses. ${ }^{59}$

\section{On a separate file}

Fig. 3.4.2 CD titration series for some platinum complexes with GC DNA (200 $\mu \mathrm{M}, 50 \mathrm{mM} \mathrm{NaCl}$, except for [Pt-2] where it is $20 \mathrm{mM} \mathrm{NaCl}$ and [Pt-8] where it is $100 \mu \mathrm{M}$ DNA, $10 \mathrm{mM} \mathrm{NaCl})$. [Pt-X] represents [Pt(L)Cl(DMSO)] (HL=R'C(O)NHC(S)NR ${ }_{2}$ : $\mathrm{R}^{\prime}=$ aryl, $\mathrm{NR}_{2}=$ amine) where for [Pt-2], $\mathrm{NR}_{2}=\mathrm{N}\left(\mathrm{CH}_{2} \mathrm{CH}_{3}\right)_{2}$ and $\mathrm{R}^{\prime}=\mathrm{NO}_{2}$, for [Pt-3], $\mathrm{NR}_{2}=\mathrm{N}\left(\mathrm{CH}_{2} \mathrm{CH}_{3}\right)_{2}$ and $\mathrm{R}^{\prime}=\mathrm{OCH}{ }_{3}$, for [Pt-5], $\mathrm{NR}_{2}=\mathrm{NO} 4\left(\mathrm{CH}_{2}\right)$ and $\mathrm{R}^{\prime}=\mathrm{NO}_{2}$, for [Pt-6], $\mathrm{NR}_{2}=\mathrm{NO} 4\left(\mathrm{CH}_{2}\right)$ and $\mathrm{R}^{\prime}=\mathrm{OCH}_{3}$, for [Pt-8], $\mathrm{NR}_{2}=\mathrm{N}\left(\mathrm{CH}_{2} \mathrm{CH}_{2} \mathrm{OH}\right)_{2}$ and $\mathrm{R}^{\prime}=\mathrm{NO}_{2}$ and for [Pt-9], $\mathrm{NR}_{2}=\mathrm{N}\left(\mathrm{CH}_{2} \mathrm{CH}_{2} \mathrm{OH}\right)_{2}$ and $\mathrm{R}^{\prime}=\mathrm{OCH}_{3}$. DNA base : [Pt-X] ratios are in increasing order of $\mathrm{CD}$ at $320 \mathrm{~nm}$ as indicated on the figures. $^{47}$

\section{On a separate file}

Fig. 3.4.3 Displacement from poly[d(G-C) $]_{2}(60 \mu \mathrm{M}$ base) of a racemic methyl substituted analogue of the helicate of Fig. 2.2.4.1 $(6 \mu \mathrm{M})$ by $\left[\mathrm{Co}\left(\mathrm{NH}_{3}\right)_{6}\right]^{3+}$ and the conqequent change of the $290 \mathrm{~nm} \mathrm{CD}$ signal from the positive of B-DNA to negative of Z-DNA. ${ }^{48}$

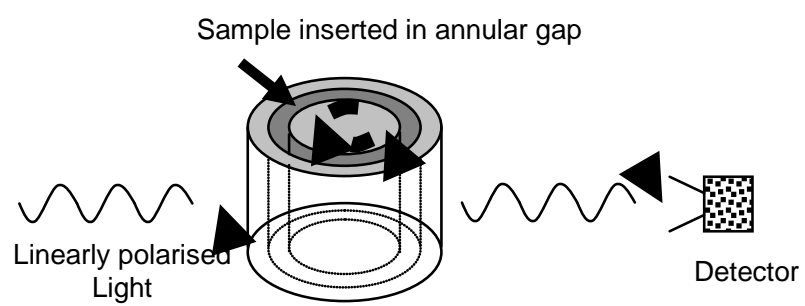

Fig. 3.5.1 Schematic diagram of Couette flow cell. ${ }^{49}$

\section{On a separate file}

Fig. 3.5.2 LD spectra of (a) (R)- $\mathrm{L}_{3}$, (b) (M)- $\mathrm{L}_{3}$ and (c) (P)- $\mathrm{L}_{3}$ binding to ct-DNA at constant DNA (500 $\left.\mu \mathrm{M}\right)$ and increasing metal complex $(0-50 \mu \mathrm{M})$ concentration. Water was subtracted from each sample spectra and the data zeroed at $420 \mathrm{~nm}$ for the racemic metal complex and enantiomers. L3 is 3-methyl subsituted version of the helicate described in Fig. 2.2.5.1.

Black and white photographs of the authors are attached. 